\title{
Systematic Study of Pt-Ru/C Catalysts Prepared by Chemical Deposition for Direct Methanol Fuel Cells
}

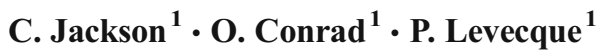

Published online: 18 February 2017

(C) The Author(s) 2017. This article is published with open access at Springerlink.com

\begin{abstract}
In this research, the activity and stability for methanol electro-oxidation on $\mathrm{Pt}-\mathrm{Ru} / \mathrm{C}$ catalysts was increased by optimising the catalyst preparation method. The $\mathrm{Pt}-\mathrm{Ru} / \mathrm{C}$ catalysts were synthesised using $\mathrm{Pt}(\mathrm{acac})_{2}$ and $\mathrm{Ru}(\mathrm{acac})_{3}$ precursors for chemical deposition of the metals. Performance of the catalyst was examined by cyclic voltammetry and chronoamperometry in a methanolcontaining electrolyte. TEM, EDS, X-ray photoelectron spectroscopy and XRD were used to physically characterise the catalysts. The parameters investigated were precursor decomposition phase, synthesis temperature and $\mathrm{Pt} / \mathrm{Ru}$ ratio. Precursor deposition from the liquid phase was more active for methanol electro-oxidation, predominantly due to particle size and degree of alloying achieved during this precursor decomposition phase. Synthesis temperature affected the particle size, active surface area, ruthenium oxidation state and degree of alloying which in turn affected catalyst stability and activity for methanol electro-oxidation. The $\mathrm{Pt} / \mathrm{Ru}$ ratio greatly affects the performance of the catalyst. The catalyst with the highest activity for methanol electro-oxidation was the catalyst synthesised at $350{ }^{\circ} \mathrm{C}$ with a $\mathrm{Pt} / \mathrm{Ru}$ ratio of 50:50.
\end{abstract}

Keywords Direct methanol fuel cell · Platinum · Ruthenium · Electrocatalysis - Thermally induced chemical deposition

P. Levecque

pieter.levecque@uct.ac.za

1 HySA/Catalysis Centre of Competence, Centre for Catalysis Research, Department of Chemical Engineering, University of Cape Town, Rondebosch 7701, South Africa

\section{Introduction}

Methanol is considered to be the most promising alcohol for portable and microfuel cell applications since methanol is a liquid under atmospheric conditions, synthesised easily and inexpensively, with a specific energy density of $6 \mathrm{kWh} \mathrm{kg}^{-1}$ [1]. Therefore, the direct methanol fuel cell (DMFC) is a promising alternative to conventional batteries, as they offer longer run times and methanol can be easily replenished from the fuel storage. This would translate into a longer battery life and more power available on portable devices. In addition, the DMFC would have the advantage of instantaneous refuelling, unlike the rechargeable battery which requires hours to restore power. Despite the many advantages of DMFC's over hydrogen polymer electrolyte fuel cells (PEFC's), the drawbacks of DMFC's are the high cost of materials used in fabrication, the crossover of methanol from the anode to the cathode, ruthenium dissolution and crossover from the anode to the cathode, low efficiency and low power density [2]. Due to the low activity of the catalyst at the anode, catalyst loading at the anode is approximately ten times that of the catalyst loading in the hydrogen PEMFC. The high catalyst loading increases mass transfer limitations which further decreases the efficiency at the anode [3].

Carbon-supported Pt-Ru catalysts are considered to currently be the best catalysts for the anode of the DMFC because of their tolerance of the carbon oxygenate intermediate of the methanol electro-oxidation reaction and activity towards the water splitting reaction [4]. These $\mathrm{Pt}-\mathrm{Ru} / \mathrm{C}$ catalysts are usually prepared by chemical reduction of $\mathrm{H}_{2} \mathrm{PtCl}_{6}$ and $\mathrm{RuCl}_{3}$ precursors with an atomic ratio of $\mathrm{Pt}_{0.5} \mathrm{Ru}_{0.5}$ [5]. However, it has been proposed that catalyst precursors containing chloride have lower activity and stability than non-chloride precursors since the chloride deactivates the active sites on the catalyst [6]. This 
optimum ratio of $\mathrm{Pt} / \mathrm{Ru}$, morphology, degree of alloying and particle size is highly contested since optimum conditions are easily influenced by slight variations in preparation methods [5].

The organo-metallic chemical vapour deposition (OMCVD) synthesis method has many advantages over wet synthesis. Namely, it is a 'one-step' process which is less time consuming since it allows lengthy stages, involved in the wet chemistry method, to be avoided [7]. In addition, the mixing of catalyst precursors in the OMCVD method occurs in the vapour phase. This allows for small particle production, excellent uniformity and an enhanced level of control over metal loading, since the decomposition occurs at the same time and in a more controlled manner [8]. The CVD process is a promising catalyst synthesis method because small particles are produced which show excellent electrochemical properties in PEFC's [9]. The aim of this study was to investigate the characteristics and electrochemical performance for methanol electro-oxidation of Pt$\mathrm{Ru} / \mathrm{C}$ catalysts prepared by OMCVD method and a new method which involves precursor decomposition before vapourisation. The effect of varied precursor decomposition phase, synthesis temperature and $\mathrm{Pt} / \mathrm{Ru}$ ratio was investigated.

\section{Experimental}

\section{Preparation of Catalysts}

$\mathrm{Pt}(\mathrm{acac})_{2}$ and $\mathrm{Ru}(\mathrm{acac})_{3}$ were used as precursors for $\mathrm{Pt}$ and $\mathrm{Ru}$, respectively, supported on carbon black (Vulcan $\mathrm{XC}-72 \mathrm{R})$. The precursors and carbon black were mixed well to produce $0.25 \mathrm{~g}$ of $\mathrm{Pt}-\mathrm{Ru} / \mathrm{C}$ catalysts with varying $\mathrm{Pt} / \mathrm{Ru}$ ratios by thermally induced chemical deposition $[10,11]$. The catalysts were prepared in a tubular furnace, under argon ( 2 bars) and vacuum (0.01 bar) atmospheres at $350{ }^{\circ} \mathrm{C}$ for $4 \mathrm{~h}$. Catalysts were prepared with varying operating temperatures for $4 \mathrm{~h}$ under a 2-bar argon atmosphere. Catalysts prepared with different $\mathrm{Pt} / \mathrm{Ru}$ ratios were prepared at $350{ }^{\circ} \mathrm{C}$ for $30 \mathrm{~min}$.

\section{Preparation of the Working Electrode}

The catalyst ink was prepared in a glass vial by adding $5 \mathrm{mg}$ of the catalyst to $5.5 \mathrm{~mL}$ of $18.2 \mathrm{~m} \Omega \mathrm{cm}$ deionised water (MilliQ), $1 \mathrm{~mL}$ of isopropanol (Kimix) and $50 \mu \mathrm{L}$ of $5 \mathrm{wt} . \%$ Nafion solution. The mixture was sealed in the vial, the vial placed in a beaker of ice and sonicated for $30 \mathrm{~min}$. A micropipette was used to place $10 \mu \mathrm{L}$ of the catalyst ink onto the working electrode, which was a 5-mm diameter glassy carbon disc electrode, polished with 1 and $0.05 \mu \mathrm{m}$ alumina paste. The electrode was left in air to dry.

\section{Electrochemical Experiments}

The electrochemical characterisation experiments were conducted in a three-electrode electrochemical cell. A glassy carbon electrode coated with catalyst ink was used as the working electrode; a $\mathrm{Pt}$ wire as a counter electrode and $\mathrm{Hg} / \mathrm{HgSO}_{4}$ reference electrode were used for the electrochemical experiments. All potentials were corrected and reported using the standard hydrogen electrode (SHE). A 0.5- $\mathrm{M} \mathrm{H}_{2} \mathrm{SO}_{4}$ (95$98 \% \mathrm{H}_{2} \mathrm{SO}_{4}$ Sigma-Aldrich Reagent Grade) electrolyte solution was used for cyclic voltammetry experiments and prepared using $18.2 \mathrm{~m} \Omega \mathrm{cm}$ deionised water and concentrated $\mathrm{H}_{2} \mathrm{SO}_{4}$. A $0.5-\mathrm{M} \mathrm{H}_{2} \mathrm{SO}_{4}$ and $1 \mathrm{M} \mathrm{MeOH}$ (99.9\% SigmaAldrich CHROMASOLV) electrolyte solution was used for the methanol oxidation cyclic voltammetry, prepared using $18.2 \mathrm{~m} \Omega \mathrm{cm}$ deionised water, concentrated $\mathrm{H}_{2} \mathrm{SO}_{4}$ and 99.9\% $\mathrm{MeOH}$. The electrolyte solution was purged for 30 min with argon and was slowly bubbled through the electrolyte throughout the experiments. The potential of the working electrode was cycled between 0 and $0.7 \mathrm{~V}$ vs. SHE at $100 \mathrm{mV}$ for 50 cycles; the scan rate was then reduced to $50 \mathrm{mV}$ and cycled between 0 and $0.7 \mathrm{~V}$ vs. SHE for 5 cycles. The chronoamperometry experiments were performed in an argon-saturated $0.5 \mathrm{M} \mathrm{H}_{2} \mathrm{SO}_{4}$ and $1 \mathrm{M} \mathrm{MeOH}$ electrolyte solution. The electrolyte was deoxygenated by purging the system with argon for $30 \mathrm{~min}$. The potential was then set at $0.1 \mathrm{~V}$ vs. SHE and stepped to $0.5 \mathrm{~V}$ vs. SHE. The CO stripping voltammetry experiments were performed by initially purging the electrolyte with $\mathrm{CO}$ for $20 \mathrm{~min}$ whilst holding the potential of the working electrode at $0.1 \mathrm{~V}$ vs. SHE. The cell is subsequently purged with argon for $20 \mathrm{~min}$ whilst holding the potential at $0.1 \mathrm{~V}$ vs. SHE. The potential, starting at $0.1 \mathrm{~V}$ vs. SHE, is cycled between 0 and $0.8 \mathrm{~V}$ vs. SHE at $50 \mathrm{mV} / \mathrm{s}$ for 5 cycles.

\section{Physical Characterisation}

Transmission Electron Microscope (TEM) was carried out on a Tecnai G2 electron microscope operating at $200 \mathrm{kV}$. Energydispersive X-ray spectroscopy (EDX) coupled to a scanning electron microscopy (SEM) was carried out on a FEI Field Emission Nova NanoSEM 230, using an Oxford X-Max detector and INCA software, at $30 \mathrm{kV}$. X-ray Diffraction (XRD) was carried out on a Bruker D8 Advance diffractometer with a $\mathrm{Co} \mathrm{K} \alpha$ radiation source operating at $40 \mathrm{kV}$. The $\mathrm{Pt}-\mathrm{Ru} / \mathrm{C}$ catalyst was placed in the sample holder, and the X-ray angle was increased from $10^{\circ}$ to $130^{\circ}$ at $2^{\circ}$ per minute. X-ray photoelectron spectroscopy was carried out on a PHI 5000 Scanning ESCA Microprobe with a $100-\mu \mathrm{m}$ diameter monochromatic Al $\mathrm{K} \alpha \mathrm{X}$-ray beam $(\mathrm{h} v=1486.6 \mathrm{eV})$ generated by a $25-\mathrm{W}$; $15 \mathrm{kV}$ electron beam is used to analyse the different binding energy peaks. 


\section{Results and Discussion}

\section{Effect of Catalyst Preparation Atmosphere}

The effect of catalyst preparation atmosphere was investigated by preparing catalysts under a 2-bar argon atmosphere and a 0.01-bar vacuum atmosphere.

The Clausius-Clapeyron constants for $\mathrm{Pt}(\mathrm{acac})_{2}$ and $\mathrm{Ru}(\mathrm{acac})_{3}$ were reported by Morozova et al. [12]. These were used to calculate boiling points of the precursors and could be compared to literature values of melting and decomposition temperatures reported in literature $[13,14]$. The catalysts produced under an argon atmosphere at 2 bars decompose from the liquid phase whereas catalysts produced under a vacuum atmosphere decompose from the vapour phase.

Figure 1 shows the TEM images of catalysts prepared under different pressures and gaseous atmospheres at $350{ }^{\circ} \mathrm{C}$ for $4 \mathrm{~h}$. Figure $1 \mathrm{a}$ is the TEM image of the catalyst prepared under a pressurised argon atmosphere, and Fig. $1 \mathrm{~b}$ is the TEM image for the catalyst prepared under a vacuum atmosphere. Figure 1a, b both have well-distributed and small Pt-Ru nano-sized particles of around 3 and $2 \mathrm{~nm}$, respectively. It can be seen from the particle size distribution graphs that the catalyst prepared under a vacuum atmosphere has a narrower particle size distribution around a smaller average particle size than the catalyst prepared under a pressurised atmosphere. The difference in particle size could be due to the precursor phase before decomposition, as smaller particles are produced when decomposition takes place from the vapour phase whilst slightly larger particles are produced when precursor decomposition occurs from the liquid phase.

The Debye-Scherrer equation was used to calculate the average crystallite size in all the samples from the XRD diffraction curves [15]. The $\mathrm{Pt}(111)$ and $\mathrm{Pt}(220)$ peaks are used to calculate the average crystallite sizes indicated in Table 1 . The lattice constant was calculated using the d-spacing of $\mathrm{Pt}(111)$ and $\mathrm{Pt}(220)$ peaks, and the ruthenium atomic fraction in $\mathrm{Pt}-\mathrm{Ru}$ was calculated using Vegard's law for all prepared catalysts [16]. The lattice constants and ruthenium fraction included in the Pt-Ru structure are also reported in Table 1.

The crystal lattice of Pt will contract as the smaller ruthenium atoms are included in the crystal structure [17]. Platinum is a larger atom $(1.39 \AA)$ and therefore has a larger particle size in a cluster; however, ruthenium is a smaller atom (1.34 $\AA$ ) and when included into the platinum cluster, the particle size is decreased this translates into a decrease in lattice spacing and lattice constant. Therefore, the lattice constant is inversely proportional to the ruthenium included in the platinum lattice, since a decrease in lattice constant is due to an increase in ruthenium content in the lattice [18]. In addition, an increase in ruthenium in the platinum lattice is illustrative of the degree of alloying in the catalyst. The increase in ruthenium atomic fraction in the metal structure is due to better atomic level mixing of metals and alloying; hence, the liquid phase decomposition allows for better alloying of the metals (Table 2).

X-ray photoelectron spectroscopy (XPS) was used to determine the species of oxides and hydrous compounds on the ruthenium surface which could influence activity. The
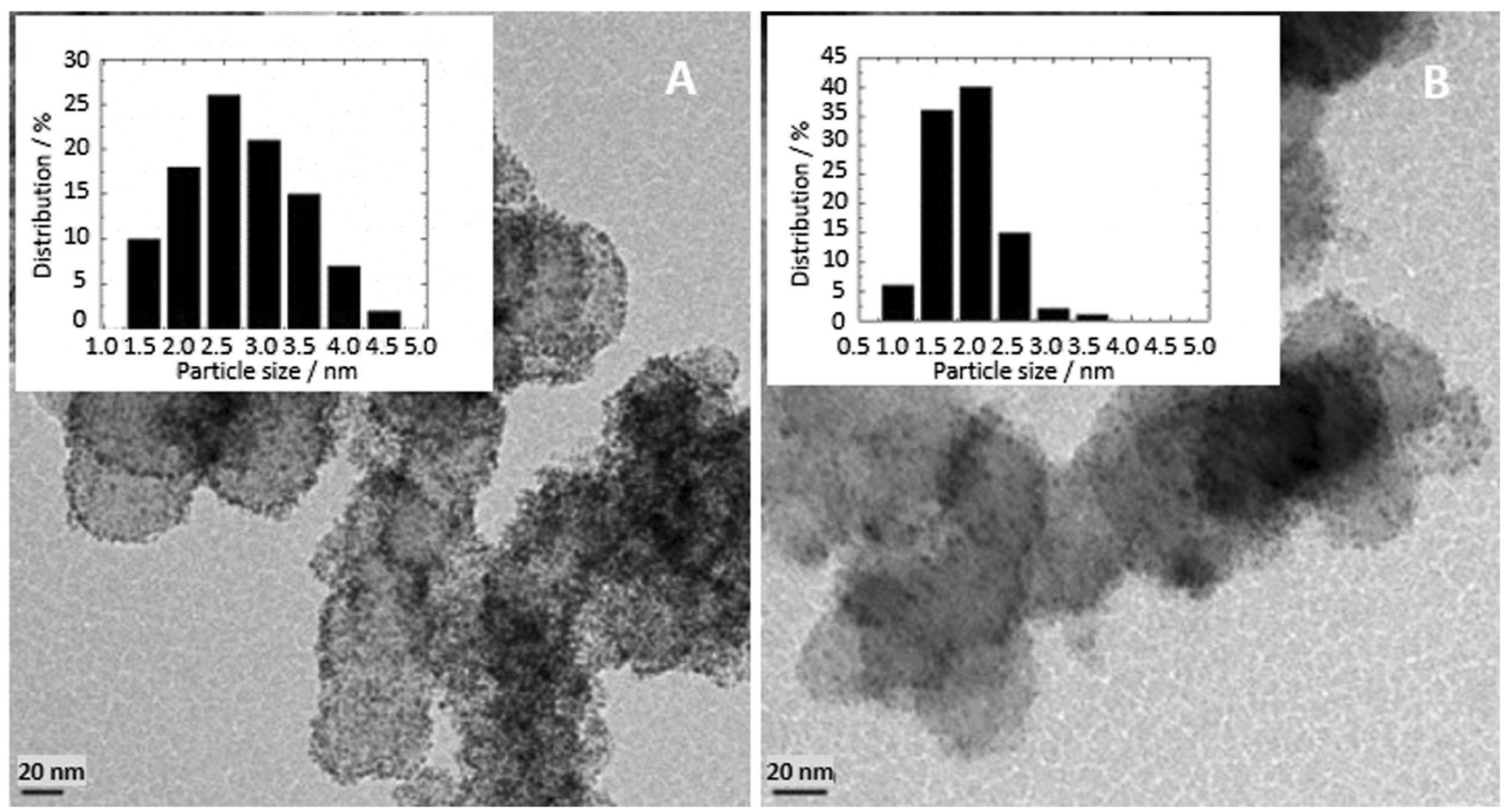

Fig. 1 TEM images at $20 \mathrm{~nm}$ resolution of Pt-Ru/C catalysts produced at $350{ }^{\circ} \mathrm{C}$ for $4 \mathrm{~h}$ under a 2 bars argon atmosphere and $\mathbf{b} 0.01$ bar vacuum atmosphere 
Table 1 Data obtained from XRD patterns for catalysts prepared under different atmospheres

\begin{tabular}{llll}
\hline $\begin{array}{l}\text { Preparation } \\
\text { atmosphere }\end{array}$ & $\begin{array}{l}\text { Crystallite size } \\
(\mathrm{nm})\end{array}$ & $\begin{array}{l}\text { Lattice } \\
\text { constant }(\AA)\end{array}$ & $\begin{array}{l}\text { Ruthenium in Pt- } \\
\mathrm{Ru}(\%)\end{array}$ \\
\hline Argon & 2.8 & 3.91 & 25.3 \\
Vacuum & 2.3 & 3.92 & 17.6 \\
\hline
\end{tabular}

ruthenium $3 d$ electron configuration was evaluated and the binding energies gave insight into the potential compounds. The XPS results from the deconvolution of the Ru $3 \mathrm{~d}$ peaks shows a lower $\mathrm{Ru}$ oxidation state for the catalyst prepared under an argon atmosphere. In the case of the vacuum atmosphere prepared catalyst, no pure metals were seen on the catalyst surface; instead, the $\mathrm{Ru} 3 \mathrm{~d}$ peak suggests $\mathrm{RuO}_{2}$ compounds. The organic O-C-H species seen in the argon prepared catalyst is feasibly residue from the organic $\mathrm{Ru}(\mathrm{acac})_{3}$ precursor. On the contrary, the oxide species on the vacuum prepared catalyst is likely formed from residual air in the vacuum.

Cyclic voltammograms were used to characterise the Pt-Ru catalysts by analysing the changes in shape and pseudocapacitance between catalysts. The cyclic voltammograms for the catalysts prepared under an argon and vacuum atmosphere are shown in Fig. 2. The current densities were normalised to a percentage of the maximum peak high in order to compare the cyclic voltammogram features. Large pseudocapacitance along the potential range is an indication of ruthenium oxide species content [19]. The large pseudocapacitance is due to the multiple oxidation states for oxidation and reduction of ruthenium which allows for ruthenium oxide to be oxidised and reduced to varying forms, some of which can continue to be reduced and oxidised [19]. The cyclic voltammetry curve of $\mathrm{RuO}_{2}$ in a $\mathrm{H}_{2} \mathrm{SO}_{4}$ electrolyte has been described as mirror like and featureless which describes the figures well. It is interesting that the cyclic voltammograms are nearly identical, since XPS indicates a difference in surface compounds. It can be suggested that the surface groups detected by XPS are properties formed during the catalyst preparation method. This preparation method would therefore influence the bulk catalyst properties, whereas the cyclic voltammograms are a reflection of the surface groups which have been oxidised to hydrous oxides in the electrolyte. The first scans were chosen in order to evaluate the surface properties of the catalyst due to preparation method rather than

Table 2 XPS results of binding energies for the $\mathrm{Ru} 3 \mathrm{~d}$ electron configuration for catalysts prepared under different atmospheres

\begin{tabular}{lll}
\hline Preparation atmosphere & Binding energy $\left(\mathrm{E}_{\mathrm{B}}\right)$ & Possible compound \\
\hline 2 bars argon & 280.4 & $\mathrm{Ru}-\mathrm{O}-\mathrm{C}-\mathrm{H}$ \\
0.01 bar vacuum & 280.7 & $\mathrm{RuO}_{2}$ \\
\hline
\end{tabular}

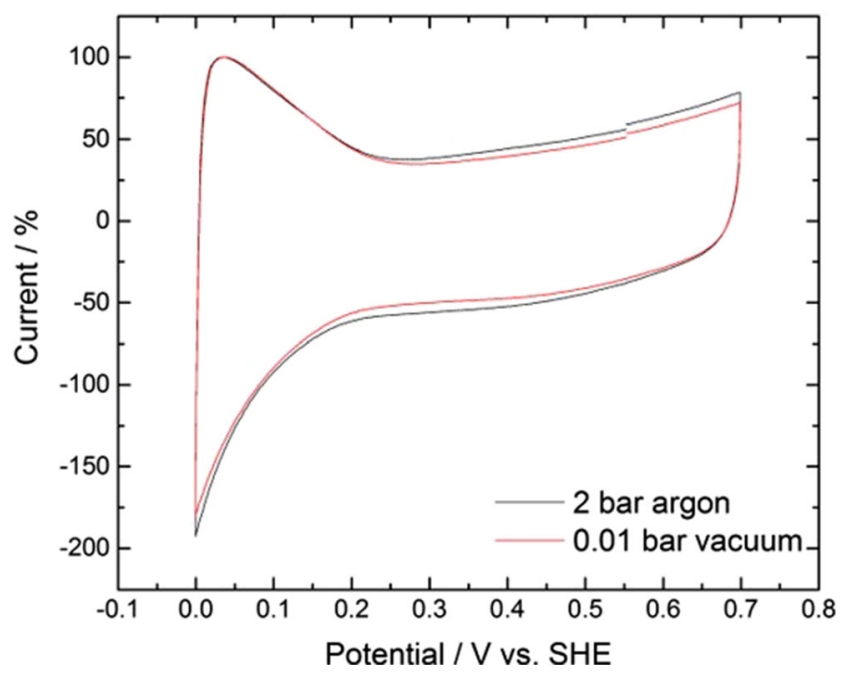

Fig. 2 First cyclic voltammograms corrected for peak height and metal weight percentage for the catalysts produced under argon and vacuum atmosphere at $350{ }^{\circ} \mathrm{C}$ for $4 \mathrm{~h}$ in an Ar-saturated $\mathrm{H}_{2} \mathrm{SO}_{4}$ electrolyte at $25^{\circ} \mathrm{C}$ and a scan rate of $100 \mathrm{mV} / \mathrm{s}$

the surface properties after cleaning cycles and changes due to potential cycling.

The electrochemically active surface area (ECSA) and CO onset potential as obtained from CO stripping voltammetry are shown in Table 3. The results show that the catalyst prepared in a vacuum atmosphere has a larger ECSA, which is expected due to the smaller particles as seen in TEM and confirmed by XRD crystallite size. Larger ECSA is seen in this study than traditionally reported; Wang et al. [5] reported an ECSA of $88 \mathrm{~m}^{2} / \mathrm{g}_{\text {metal }}$, and this correlated well with the physical surface area calculated using the particle size and densities of $\mathrm{Pt}$ and $\mathrm{Ru}$. Throughout the paper, it is assumed the high active surface areas reported in this study are due to the influence of the ruthenium oxides on the density of the metal. When the physical surface areas were calculated using the densities of pure Pt and Ru, this yielded physical surface areas of 138 and $165 \mathrm{~m}^{2} / \mathrm{g}_{\text {metal }}$, for the argon and vacuum prepared catalysts, respectively. It can be seen that the physical surface area is underestimated if this assumption is made. However, when the physical surface area is estimated using the densities of platinum and ruthenium dioxide, they are found to be $180 \mathrm{~m}^{2} / \mathrm{g}_{\text {metal }}$ for the argon atmosphere prepared catalyst and $215 \mathrm{~m}^{2} / \mathrm{g}_{\text {metal }}$ for the vacuum atmosphere prepared catalyst. Thus, the physical surface areas calculated

Table 3 Data collected from CO stripping voltammetry for catalysts prepared under different atmospheres

\begin{tabular}{lll}
\hline $\begin{array}{l}\text { Preparation } \\
\text { atmosphere }\end{array}$ & ECSA $\left(\mathrm{m}^{2} / \mathrm{g}_{\text {metal }}\right)$ & Onset potential (V vs. SHE) \\
\hline Argon & 175 & 0.411 \\
Vacuum & 201 & 0.429 \\
\hline
\end{tabular}


from the Pt- $\mathrm{RuO}_{2}$ assumption of densities follow the ECSA far better than an assumption of pure Pt-Ru.

The CO tolerance of a catalyst can be seen by the onset potential, since onset potential is directly proportional to activation energy of the $\mathrm{CO}$ oxidation reaction. Therefore, lower activation energy is translated into a higher activity and thus a more CO tolerant catalyst. Contrary to the high ECSA of the vacuum prepared catalyst, the argon prepared catalyst is more active for $\mathrm{CO}$ oxidation than the vacuum prepared catalyst. This could be attributed to the degree of alloying in the argon prepared catalyst as this is more suited to $\mathrm{CO}$ tolerance [20] or the particle morphology differences attributed to decomposition from the vapour phase vs. liquid phase. The result also contradicts previous studies which state that ruthenium oxide improves $\mathrm{CO}$ tolerance $[21,22]$, since the vacuum prepared catalyst is shown to contain $\mathrm{RuO}_{2}$. However, other studies by Long et al. investigated methanol electro-oxidation on Pt-Ru, $\mathrm{Pt}-\mathrm{RuO}_{2}$ and $\mathrm{Pt}-\mathrm{RuO}_{x} \mathrm{H}_{y}$ attributed the enhanced activity of $\mathrm{Pt}-\mathrm{RuO}_{x} \mathrm{H}_{y}$ to its electron and proton conducting capabilities [23]. The conducting properties of $\mathrm{Pt}-\mathrm{RuO}_{x} \mathrm{H}_{y}$ are key in performance the for methanol electro-oxidation as they promote the formation of $\mathrm{Ru}-\mathrm{OH}$. $\mathrm{Ru}-\mathrm{OH}$ aids in $\mathrm{CO}$ tolerance on $\mathrm{Pt}$ surfaces by the bifunctional mechanism [24], and since Ru metal and anhydrous $\mathrm{RuO}_{2}$ do not have these capabilities, they are not as active for methanol electro-oxidation [25].

The methanol oxidation onset potential and percentage drop in current density in chronoamperometry curves after $30 \mathrm{~min}$ is reported in Table 4. In accordance with CO tolerance results, the catalyst prepared in an argon environment is more active for methanol oxidation. As in $\mathrm{CO}$ tolerance, the increased activity for methanol oxidation could be attributed to the differences in the degree of alloying or the particle morphology differences in the catalysts due to the decomposition phase of the precursors. Hoster et al. [26] established that rough Pt-Ru surfaces, surfaces with many defects such as steps and kinks, and surfaces formed by electrodeposition are more resistant to poisoning than smooth Pt-Ru surfaces of the same composition. The higher current density seen on the argon atmosphere prepared catalyst confirms the higher activities of this catalyst for methanol oxidation; once again, this could be due to the formation of $\mathrm{Ru}-\mathrm{OH}$ from $\mathrm{Ru}$ on the surface of the catalyst.

Table 4 Cyclic voltammetry data of methanol oxidation and chronoamperometry for catalysts prepared under different atmospheres

\begin{tabular}{llll}
\hline $\begin{array}{l}\text { Preparation } \\
\text { atmosphere }\end{array}$ & $\begin{array}{l}\text { Onset potential } \\
\text { (V vs. SHE) }\end{array}$ & $\begin{array}{l}\text { Current density at } \\
0.5 \text { V vs. SHE } \\
\left(\mathrm{A} / \mathrm{g}_{\text {metal }}\right)\end{array}$ & $\begin{array}{l}\text { Drop in } \\
\text { current density } \\
(\%)\end{array}$ \\
\hline Argon & 0.288 & 95.0 & 42.2 \\
Vacuum & 0.290 & 63.8 & 50.6 \\
\hline
\end{tabular}

A drop in current during a chronoamperometry test is an indication of the stability of the catalyst in methanol [5]. The catalyst prepared in a vacuum atmosphere had a greater drop in current from $30 \mathrm{~s}$ to $30 \mathrm{~min}$ when compared to the catalyst prepared under an argon atmosphere. A drop in chronoamperometry current is due to a plethora of reasons, such as mass transport limitations [2], ruthenium dissolution [27] and/or CO poisoning. This additional drop in the current of the vacuum prepared catalyst could be due to the smaller particle size undergoing more sintering during the chronoamperometry experiment and a higher $\mathrm{CO}$ onset potential, therefore $\mathrm{CO}$ poisoning during the methanol oxidation reactions.

\section{Effect of Catalyst Preparation Temperature}

The influence of the preparation temperature on the catalyst activity and stability was investigated to determine the optimum preparation temperature. Figure 3 displays the TEM images of catalysts prepared under different operating temperatures. Figure $3 \mathrm{a}-\mathrm{e}$ shows the TEM images for catalysts prepared at an operating temperature of 300, 350, 450, 600 and $700{ }^{\circ} \mathrm{C}$, respectively. The TEM images in Fig. 3 show well dispersed particles across all operating temperatures; however, the particle size visibly increases between temperatures 300 to $700{ }^{\circ} \mathrm{C}$. The particle size increase as temperature is increased is due to sintering of the metal particles at high temperatures, particularly at $700{ }^{\circ} \mathrm{C}$ where particle sizes of $8 \mathrm{~nm}$ are seen. Additionally, the particle size distribution at the various preparation temperatures increases as preparation temperature increases. This trend is due to an increased sintering effect as preparation temperature is increased, where particle size distributions have been shown to follow a log normal distribution with a tail towards larger particle diameters [28].

The crystallite sizes, reported in Table 5, determined from XRD correspond to those seen in the TEM analysis. The trend of increasing size with increasing temperature is also observed here. This confirms that the TEM images are representative for the catalyst, and it is unlikely that large agglomerates exist in the material. The lattice constant and ruthenium atomic fraction in Pt-Ru are also reported in Table 5. It can be seen that the average lattice constant decreases with increasing operating temperature, causing a significant increase in ruthenium fraction included in the platinum lattice as seen in literature [18]. Antolini and Cardellini concluded that the interaction of $\mathrm{Ru}$ with the carbon support hinders the formation of an alloy with Pt in the absence of thermal treatment. When thermally untreated $\mathrm{Ru}$ exists as an amorphous structure, in contrast to treatment at higher temperatures, the Ru was alloyed to form Pt-Ru. Additionally, high temperatures lead to sintering of the particles and therefore encourage further alloying of the $\mathrm{Pt}-\mathrm{Ru}$ particles, thus increasing the ruthenium fraction in the $\mathrm{Pt}-\mathrm{Ru}$ particles and decrease in lattice spacing [18]. 

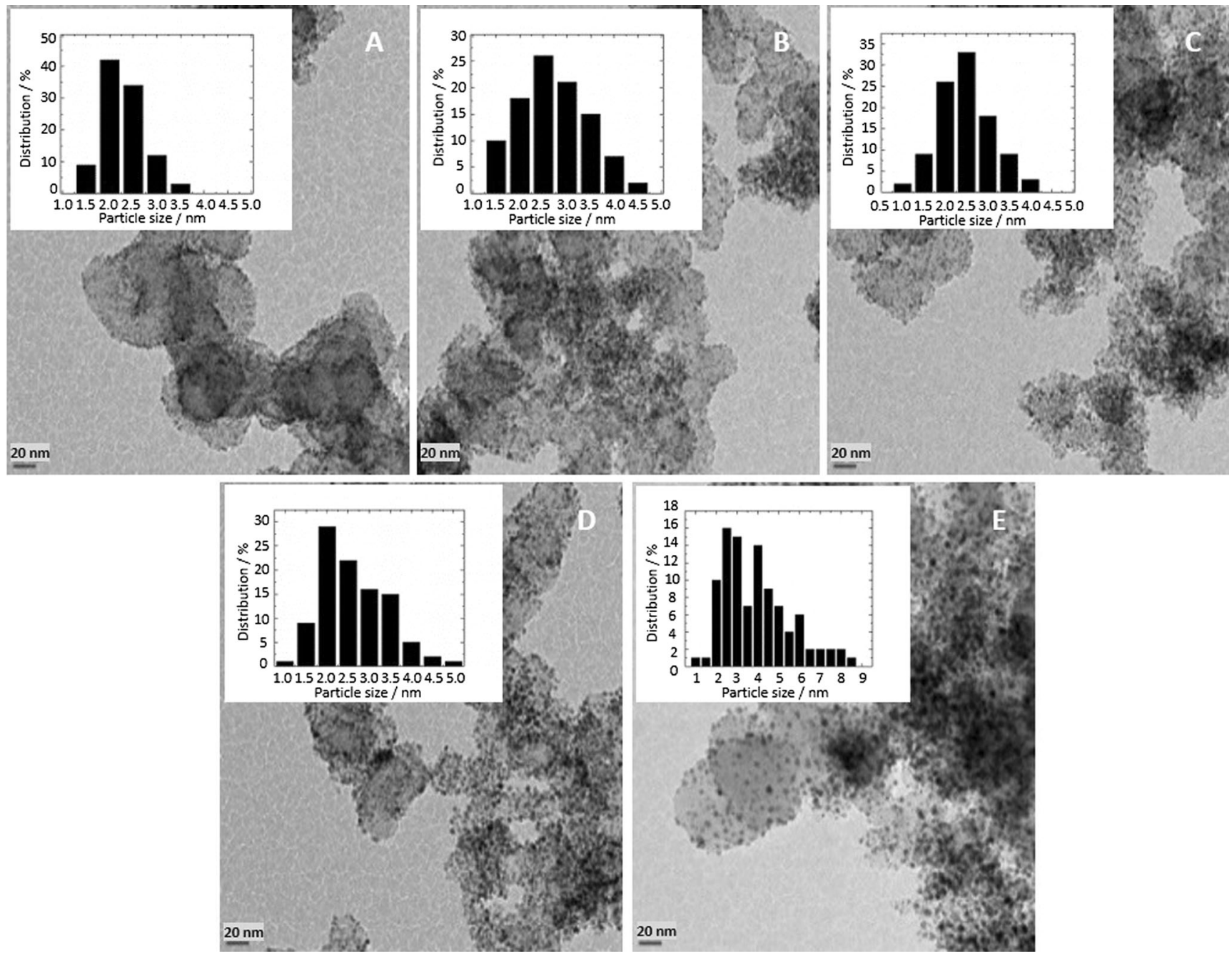

Fig. 3 TEM images at $20 \mathrm{~nm}$ resolution of Pt-Ru/C catalysts produced for $4 \mathrm{~h}$ under argon at a $300{ }^{\circ} \mathrm{C}, \mathbf{b} 350{ }^{\circ} \mathrm{C}, \mathbf{c} 450{ }^{\circ} \mathrm{C}, \mathbf{d ~} 600{ }^{\circ} \mathrm{C}$ and e $700{ }^{\circ} \mathrm{C}$

XPS of the ruthenium $3 \mathrm{~d}$ electron configurations of the catalysts prepared under different temperatures showed a decrease in the binding energy as the preparation temperature is increased, as described in Table 6. This shows the changes in ruthenium oxidation state to lower values due to increases in preparation temperature, since high temperatures are likely to drive off any precursor fragments remaining on the surface. Moreover, these catalysts were prepared in an argon

Table 5 Data obtained from XRD patterns for catalysts prepared at different temperatures

\begin{tabular}{llll}
\hline $\begin{array}{l}\text { Preparation } \\
\text { temperature }\left({ }^{\circ} \mathrm{C}\right)\end{array}$ & $\begin{array}{l}\text { Crystallite size } \\
(\mathrm{nm})\end{array}$ & $\begin{array}{l}\text { Lattice } \\
\text { constant }\end{array}$ & $\begin{array}{l}\text { Ruthenium in Pt- } \\
\mathrm{Ru}(\%)\end{array}$ \\
\hline 300 & 2.2 & 3.94 & 5.56 \\
350 & 2.8 & 3.91 & 25.3 \\
450 & 2.8 & 3.90 & 38.0 \\
600 & 3.4 & 3.89 & 47.1 \\
700 & 4.3 & 3.88 & 53.6 \\
\hline
\end{tabular}

atmosphere; therefore, $\mathrm{RuO}_{2}$ does not form on the metal surface once the precursor has completely decomposed since there is no residue oxygen in the preparation atmosphere as seen in the vacuum atmosphere prepared catalyst. Table 6 definitively shows the progression of organic species on the ruthenium surface at low temperatures to reduced ruthenium metal at $700{ }^{\circ} \mathrm{C}$.

Figure 4 compares the first cycles of the catalysts produced at different temperatures, corrected for the maximum height. The first cycle of the cyclic voltammogram for the catalyst prepared at a temperature of 300 and $700{ }^{\circ} \mathrm{C}$, respectively, shows a vast difference in catalyst composition. The cyclic voltammogram of the catalyst prepared at $300{ }^{\circ} \mathrm{C}$ is more featureless and has a large pseudo-capacitance, indicating a high ruthenium oxide or hydrous oxide content [19]. The catalyst produced at $700{ }^{\circ} \mathrm{C}$ has defining platinum features and a small pseudo-capacitance, indicating a lower ruthenium oxide or hydrous oxide content. Figure 4 gives a strong indication that catalysts produced at high temperatures contain more ruthenium metal whilst catalysts produced at low temperatures 
Table 6 XPS results of binding energies for the $\mathrm{Ru} 3 \mathrm{~d}$ electron configuration for catalysts prepared under different temperatures

\begin{tabular}{lll}
\hline Preparation temperature $\left({ }^{\circ} \mathrm{C}\right)$ & Binding energy $\left(\mathrm{E}_{\mathrm{B}}\right)$ & Possible compound \\
\hline 300 & 280.5 & Ru-O-C-H \\
350 & 280.5 & Ru-O-C-H \\
700 & 279.8 & Ru \\
\hline
\end{tabular}

contain a high ruthenium oxide or hydrous oxide content, as confirmed by the XPS data collected in Table 6.

The ECSA for catalysts prepared at different operating temperatures is shown in Table 7. As expected, the ECSA of the catalysts is inversely proportional to the particle size since an increase in particle size reduces the surface to volume ratio of the prepared catalyst. The drastic difference in ECSA between the $300{ }^{\circ} \mathrm{C}$ and $700{ }^{\circ} \mathrm{C}$ prepared catalysts cannot, however, be simply explained by particle size as the particle size difference between these two catalysts is not large when calculating the physical surface area. In accordance with what is seen in XPS, the physical surface area and calculated ECSAs for $300{ }^{\circ} \mathrm{C}$ prepared catalyst follow more closely when the assumption of $\mathrm{Pt}-\mathrm{RuO}_{2}$ densities is made, whereas the ECSA of the $700{ }^{\circ} \mathrm{C}$ prepared catalyst follows the physical surface area when the assumption of Pt-Ru density is made. Therefore, it is suggested that the difference in available ECSA is strongly influenced by the oxidation state of the Ru.

The optimum catalyst preparation operating temperature for $\mathrm{CO}$ tolerance, in this series, was found to be $350^{\circ} \mathrm{C}$ since the catalyst prepared at this temperature has the lowest onset potential. The $\mathrm{CO}$ oxidation onset potential is influenced by morphology of the catalyst, as this is a vital component in the activity of the catalyst for $\mathrm{CO}$ oxidation. Morphology effects such as ruthenium oxidation state, degree of alloying and

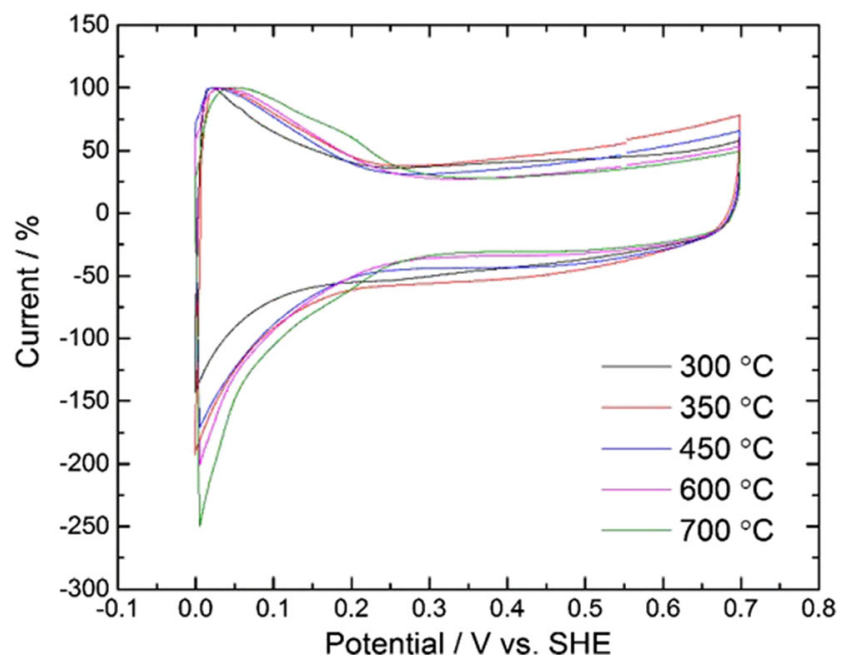

Fig. 4 First cyclic voltammograms corrected for peak height and metal weight percentage for the catalysts produced under argon at different operating temperatures for $4 \mathrm{~h}$ in an Ar-saturated $\mathrm{H}_{2} \mathrm{SO}_{4}$ electrolyte at $25^{\circ} \mathrm{C}$ and a scan rate of $100 \mathrm{mV} / \mathrm{s}$
Table 7 Data collected from CO stripping voltammetry for catalysts prepared at different temperatures

\begin{tabular}{lll}
\hline $\begin{array}{l}\text { Preparation temperature } \\
\left({ }^{\circ} \mathrm{C}\right)\end{array}$ & $\begin{array}{l}\text { ECSA }\left(\mathrm{m}^{2} /\right. \\
\left.\mathrm{g}_{\text {metal }}\right)\end{array}$ & $\begin{array}{l}\text { Onset potential }(\mathrm{V} \text { vs. } \\
\mathrm{SHE})\end{array}$ \\
\hline 300 & 218 & 0.417 \\
350 & 175 & 0.411 \\
450 & 175 & 0.430 \\
600 & 103 & 0.450 \\
700 & 75.7 & 0.455 \\
\hline
\end{tabular}

particle size play a large role in activity, although not well understood in literature [21-23, 25]. As temperature is increased, the particle size increases and ruthenium oxidation state is decreased; therefore, the morphology changes which translates into different active sites for CO oxidation.

Additionally, the $\mathrm{Pt}(111) / \mathrm{Ru}$ catalyst surface is known to be very active surface for CO oxidation [29] and using the tradition model described by Kinoshita [30], the Pt(111) surface coverage is highest between 2 and $3 \mathrm{~nm}$. Therefore, it is expected that the catalysts prepared at lower temperatures, and thus have smaller particle sizes, would be more CO tolerant. Moreover, as the ruthenium oxide and hydrous oxide content decreases, the $\mathrm{CO}$ tolerance decreases as described in literature [21]. The increase in CO oxidation onset potential is also partly due to the increasing ruthenium content in the Pt-Ru structure and decrease in ruthenium hydrous oxide content, with a mostly unalloyed catalyst at $350{ }^{\circ} \mathrm{C}$ [20] as well as temperature effects on the morphology of the catalyst.

The methanol oxidation onset potential and percentage drop in current density in chronoamperometry curves after $30 \mathrm{~min}$ is reported in Table 8 . Correspondingly to the $\mathrm{CO}$ tolerance, the operating temperature with the best results according to onset potential for methanol oxidation is $350{ }^{\circ} \mathrm{C}$. Once again, this is likely due to morphology and ruthenium oxidation state changes as the operation temperature increases. The particle size decreased as temperature is decreased; therefore, following with the $\mathrm{CO}$ tolerance, the

Table 8 Cyclic voltammetry data of methanol oxidation and chronoamperometry for catalysts prepared at different temperatures

\begin{tabular}{llll}
$\begin{array}{l}\text { Preparation } \\
\text { temperature } \\
\left({ }^{\circ} \mathrm{C}\right)\end{array}$ & $\begin{array}{l}\text { Onset potential } \\
(\mathrm{V} v \text { vs. SHE) }\end{array}$ & $\begin{array}{l}\text { Current at } 0.5 \mathrm{~V} \text { vs. } \\
\text { SHE }\left(\mathrm{A} / \mathrm{g}_{\text {metal }}\right)\end{array}$ & $\begin{array}{l}\text { Drop in current } \\
\text { density }(\%)\end{array}$ \\
\hline 300 & 0.282 & 82.0 & 46.2 \\
350 & 0.278 & 95.0 & 42.2 \\
450 & 0.303 & 59.8 & 48.8 \\
600 & 0.329 & 30.9 & 53.4 \\
700 & 0.343 & 41.5 & 56.3 \\
\hline
\end{tabular}


$\mathrm{Pt}(111) / \mathrm{Ru}$ catalyst has shown increased methanol oxidation performance [26] and these particle sizes are known to have the highest $\mathrm{Pt}(111)$ surface coverage [30]. Additionally, the oxidation of methanol has been shown to take place preferably on rough surfaces [26]; this type of surface could be produced at low temperatures rather than high temperatures, since smaller particles contain more corner and edge sites. This trend can also be seen in the specific current, where the highest current, i.e. the most active surface was observed for $350{ }^{\circ} \mathrm{C}$.

The chronoamperometry experiment follows the same trend as the methanol oxidation experiment, showing the consistence of these results. It is important to note the decrease in catalyst stability as operating temperature increases. This could be explained by the increase in $\mathrm{CO}$ tolerance as the preparation temperature decreases; therefore, less $\mathrm{CO}$ poisoning occurs on these catalysts at $0.5 \mathrm{~V}$ vs. SHE. The increased temperature must therefore produce a catalyst morphology which is less stable than catalysts produced at lower temperatures.

\section{Effect of Pt/Ru Ratio}

The effect of varying $\mathrm{Pt} / \mathrm{Ru}$ atomic ratios were investigated for their influence on the activity and stability of the catalysts for CO oxidation and methanol oxidation. Figure 5 displays the TEM images of catalysts prepared with different $\mathrm{Pt} / \mathrm{Ru}$ ratios at $350{ }^{\circ} \mathrm{C}$. Figure $5 \mathrm{a}-\mathrm{f}$ shows the TEM images for catalysts prepared with $\mathrm{Pt} / \mathrm{Ru}$ ratios of 60:40, 50:50, 60:40, 75:25, 80:20 and 90:10, respectively. These images show welldispersed particles across all catalyst Pt-Ru ratios; however, as the platinum percentage in the metal increases, a visible increase in catalyst particle size can be observed. The increase in particle size is predominantly due the sizes of the metals included. Platinum is a larger atom and therefore has a larger particle size in a cluster; thus, when ruthenium is included into the platinum cluster, the particle size is decreased.

The crystallite size calculated from the XRD diffraction curve is reported in Table 9 along with the lattice constant and $\mathrm{Ru}$ atomic fraction alloyed calculated using peaks
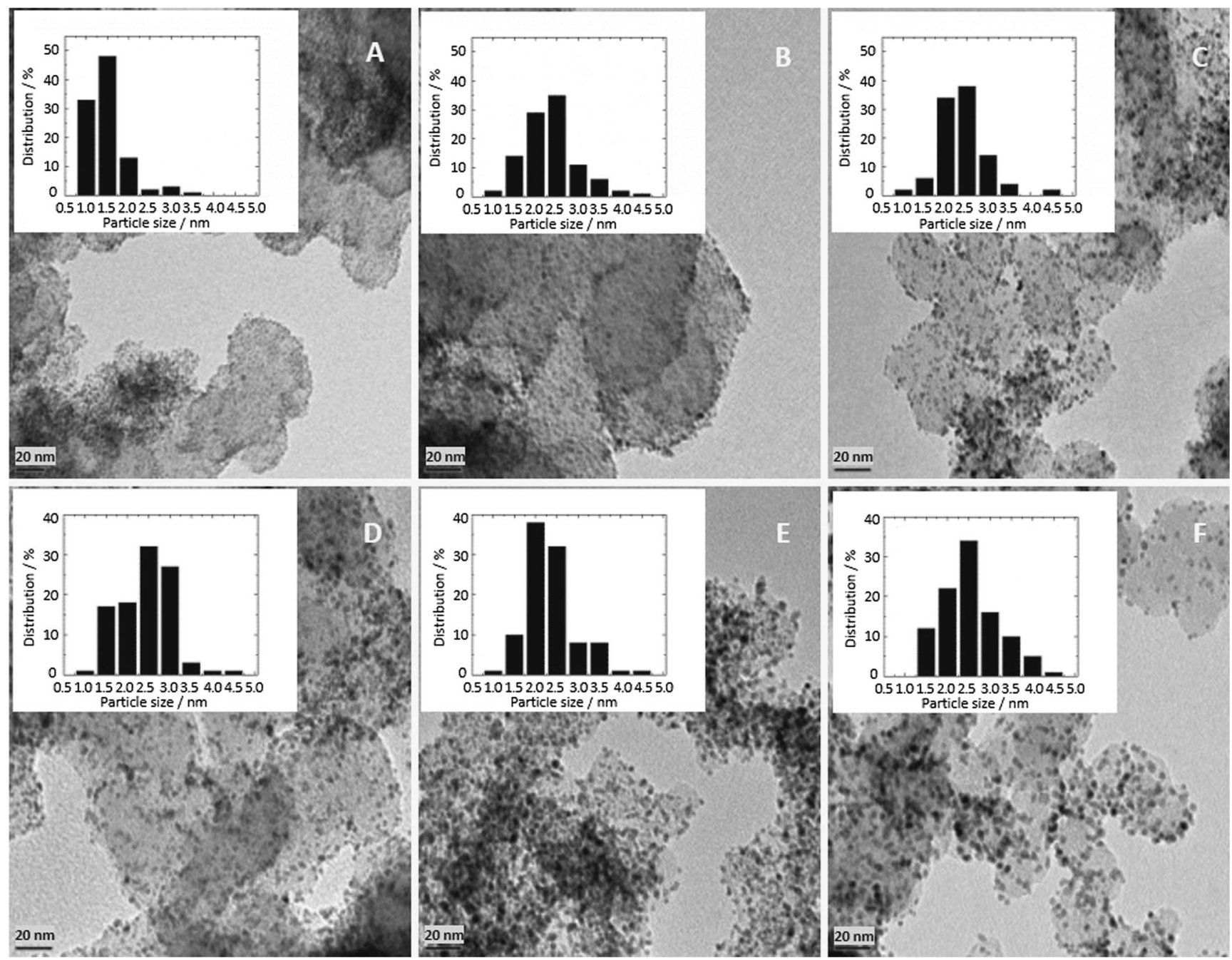

Fig. 5 TEM images at $20 \mathrm{~nm}$ resolution of Pt-Ru/C catalysts produced with different $\mathrm{Pt} / \mathrm{Ru}$ ratios of a 40:60, b 50:50, c 60:40, d 75:25, e 80:20 and f 90:10 
Table 9 Data obtained from XRD patterns for catalysts with prepared with varying $\mathrm{Pt} / \mathrm{Ru}$ ratios

\begin{tabular}{llll}
\hline $\begin{array}{l}\mathrm{Pt} / \mathrm{Ru} \\
\text { ratio }\end{array}$ & $\begin{array}{l}\text { Crystallite size } \\
(\mathrm{nm})\end{array}$ & $\begin{array}{l}\text { Lattice } \\
\text { constant }\end{array}$ & $\begin{array}{l}\text { Ruthenium in Pt-Ru } \\
(\%)\end{array}$ \\
\hline $40: 60$ & 2.1 & 3.92 & 21.4 \\
$50: 50$ & 2.2 & 3.92 & 18.7 \\
$60: 40$ & 2.4 & 3.92 & 17.1 \\
$75: 25$ & 2.8 & 3.93 & 15.6 \\
$80: 20$ & 3.0 & 3.93 & 15.1 \\
$90: 10$ & 3.2 & 3.93 & 12.5 \\
\hline
\end{tabular}

$\operatorname{Pt}(111)$ and $\mathrm{Pt}(220)$. The ruthenium atomic fraction in $\mathrm{Pt}-\mathrm{Ru}$ decreases as the platinum percentage in the total metal increases. This is due to less ruthenium being available to alloy with Pt. In accordance, the average lattice constant decreases as the ruthenium percentage in the metal increases. This is due to the small ruthenium particle size effect on decreasing the total particle size when included into the structure.

The catalysts reported in Table 10 were prepared under the same conditions; thus, similarities are expected in the ruthenium surface groups. As anticipated, remnants of the organic precursor are seen on the ruthenium surface of the catalysts with $\mathrm{Pt} / \mathrm{Ru}$ ratios of 40:60 and 50:50. However, slight differences in the ruthenium surface groups are perceived as the $\mathrm{Pt}$ loading is increased. Two defined oxidation states are observed on the 40:60 prepared catalyst, ruthenium metal and a $\mathrm{Ru}-\mathrm{C}-\mathrm{H}$ bond peak. This is a result of the increased concentration of ruthenium on the catalyst, which allows for peaks to be observed which were previously concealed in the background. Likewise, the low concentration of ruthenium on the catalyst with a $\mathrm{Pt} / \mathrm{Ru}$ ratio of 90:10 only allowed for a small $\mathrm{RuO}_{3}$ peak to be adequately quantified.

Figure 6 compares the first cycles of the catalysts produced with different $\mathrm{Pt} / \mathrm{Ru}$ ratios, corrected for metal loading and the maximum height. This figure shows the difference in catalyst composition between the catalysts with a $\mathrm{Pt} / \mathrm{Ru}$ ratio of 40:60 and 90:10. The cyclic voltammogram of the 40:60 ratio catalyst has a more featureless cyclic voltammogram and a large pseudo-capacitance, indicating a high ruthenium and/or ruthenium oxide content. The 90:10 ratio catalyst has clear

Table 10 XPS results of binding energies for the $\mathrm{Ru} 3 \mathrm{~d}$ electron configuration for catalysts prepared with varying $\mathrm{Pt} / \mathrm{Ru}$ ratios

\begin{tabular}{lll}
\hline Pt/Ru ratio & Binding energy $\left(E_{\mathrm{B}}\right)$ & Possible compound \\
\hline $40: 60$ & 280.0 & $\mathrm{Ru}$ \\
& 280.9 & $\mathrm{Ru}-\mathrm{C}-\mathrm{H}$ \\
$50: 50$ & 280.5 & $\mathrm{Ru}-\mathrm{O}-\mathrm{C}-\mathrm{H}$ \\
$90: 10$ & 283.0 & $\mathrm{RuO}_{3}$ \\
\hline
\end{tabular}

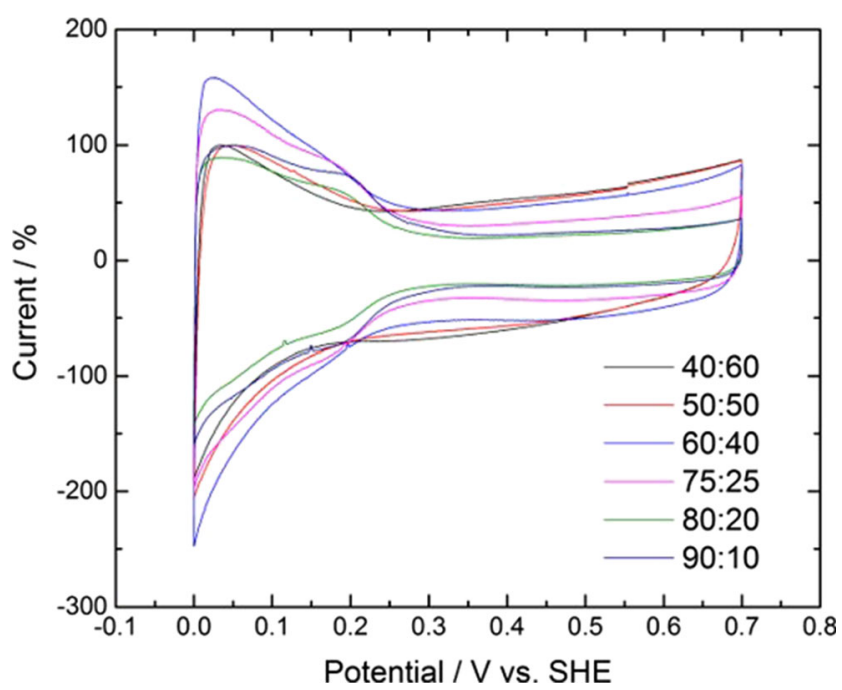

Fig. 6 First cyclic voltammograms corrected for peak height and metal weight percentage for catalysts produced with different $\mathrm{Pt} / \mathrm{Ru}$ ratios of $40: 60,50: 50,60: 40,75: 25,80: 20$ and 90:10

platinum features and a small pseudo-capacitance, indicating less ruthenium and its oxides [19].

Table 11 reports the ECSA and CO oxidation onset potential for catalysts with varying $\mathrm{Pt} / \mathrm{Ru}$ ratios. The ECSA of the prepared catalysts decreases as the platinum in the total metal increases, predominantly due to the increase in catalyst particle size and decrease in ruthenium oxide as platinum in total metal increases. This shows the ideal $\mathrm{Pt} / \mathrm{Ru}$ ratio for $\mathrm{CO}$ oxidation to be 50:50 as this has the lowest $\mathrm{CO}$ oxidation onset potential. This is in accordance with previous studies [24, 31, 32 ] as the ratio plays a role in the bifunctional mechanism, and this is the optimum ratio for the rate determining step [33]

$\mathrm{Ru}-\mathrm{OH}+\mathrm{Pt}-\mathrm{CO} \rightarrow \mathrm{Pt}+\mathrm{Ru}+\mathrm{CO}_{2}+\mathrm{H}^{+}+\mathrm{e}^{-}$

The methanol oxidation onset potential and percentage drop in current density in chronoamperometry curves after $30 \mathrm{~min}$ for catalysts produced with different $\mathrm{Pt} / \mathrm{Ru}$ ratios are shown in Table 12. An interesting result is the methanol oxidation onset potential between $\mathrm{Pt} / \mathrm{Ru}$ ratios 40:60, 50:50, $60: 40$ and 75:25, as these are nearly identical. The second

Table 11 Data collected from CO stripping voltammetry for catalysts with prepared with varying $\mathrm{Pt} / \mathrm{Ru}$ ratios

\begin{tabular}{lll}
\hline $\mathrm{Pt} / \mathrm{Ru}$ ratio & ECSA $\left(\mathrm{m}^{2} / \mathrm{g}_{\text {metal }}\right)$ & Onset potential (V vs. SHE) \\
\hline $40: 60$ & 267 & 0.392 \\
$50: 50$ & 270 & 0.386 \\
$60: 40$ & 158 & 0.449 \\
$75: 25$ & 88.7 & 0.470 \\
$80: 20$ & 69.1 & 0.460 \\
$90: 10$ & 59.4 & 0.476 \\
\hline
\end{tabular}


Table 12 Cyclic voltammetry data of methanol oxidation and chronoamperometry for catalysts with prepared with varying $\mathrm{Pt} / \mathrm{Ru}$ ratios

\begin{tabular}{llll}
\hline $\begin{array}{l}\mathrm{Pt} / \mathrm{Ru} \\
\text { ratio }\end{array}$ & $\begin{array}{l}\text { Onset potential (V } \\
\text { vs. SHE) }\end{array}$ & $\begin{array}{l}\text { Current at } 0.5 \mathrm{~V} \text { vs. } \\
\mathrm{SHE}\left(\mathrm{A} / \mathrm{g}_{\text {metal }}\right)\end{array}$ & $\begin{array}{l}\text { Drop in current } \\
\text { density (\%) }\end{array}$ \\
\hline $40: 60$ & 0.268 & 77.7 & 43.4 \\
$50: 50$ & 0.267 & 121 & 37.9 \\
$60: 40$ & 0.269 & 123 & 42.7 \\
$75: 25$ & 0.268 & 113 & 49.1 \\
$80: 20$ & 0.297 & 49.8 & 57.9 \\
$90: 10$ & 0.347 & 38.1 & 62.5 \\
\hline
\end{tabular}

indication of activity for methanol oxidation is the current at $0.5 \mathrm{~V}$ vs. SHE $\left(\mathrm{A} / \mathrm{g}_{\text {metal }}\right)$, since this is of importance in experimental work and in an operating fuel cell. Thus, the catalysts with $\mathrm{Pt} / \mathrm{Ru}$ ratios of 60:40 and 50:50 are seen to be the most active catalysts in the given range for methanol oxidation. The literature on optimum $\mathrm{Pt} / \mathrm{Ru}$ ratio varies for different researchers since catalyst preparation [2], and electrochemical testing conditions play a significant role in optimum ratio [34]. It is, however, expected that catalysts with high ruthenium oxide content would perform better for methanol oxidation than catalysts with less ruthenium oxide as shown in literature [35]. The degree of alloying itself can play a significant role, although contested between researchers.

Table 12 clearly shows that the highest currents for methanol oxidation under chronoamperometry experimental settings are found to be catalysts with ratios of 50:50 and 60:40. The stability of the catalysts tends to decrease as the platinum percentage increases; as seen in literature, this is due to the reduced alloying of $\mathrm{Ru}$ within the platinum structure. Liu and Zhang found alloyed ruthenium to be more stable in the presence of methanol than unalloyed ruthenium [35]. Chronoamperometry adds information on stability which allows the best performing catalyst in this range to be narrowed down as the catalyst with a $\mathrm{Pt} / \mathrm{Ru}$ ratio of 50:50 is the most stable catalyst.

\section{Conclusion}

This study involved the systematic investigation of operating atmosphere, temperature and $\mathrm{Pt} / \mathrm{Ru}$ ratio in catalyst preparation by organo-metallic chemical deposition. The preparation atmosphere determined the precursor decomposition phase; slightly larger Pt-Ru nano-particles were deposited on the surface of the support when precursor decomposition occurred from the liquid phase. This particle size difference resulted in different exposed Pt active sites, namely Pt(111), which increased the $\mathrm{CO}$ tolerance and methanol oxidation activity of the catalyst deposited from the liquid phase.
The operating temperature of the furnace had a significant effect of the prepared catalysts. At high operating temperatures, more ruthenium was included in the platinum structure, with less ruthenium hydrous oxides, which attributed to the poor $\mathrm{CO}$ and methanol oxidation activity at high operating temperatures. This finding is in accordance with literature stating that unalloyed Pt-Ru is more active for methanol oxidation than alloyed $\mathrm{Pt}-\mathrm{Ru}$, and ruthenium hydrous oxides are essential for high methanol oxidation activity [20-23, 25]. However, the optimum reactor temperature in the range investigated in the study was not the lowest temperature of $300^{\circ} \mathrm{C}$ but is rather $350{ }^{\circ} \mathrm{C}$. Furthermore, chronoamperometry results show an increased instability of catalysts produced at high temperatures which is an additional indication that high temperatures have a negative influence on the morphology of the catalysts.

The Pt/Ru ratio plays a vital role in the bifunctional mechanism, and this is specific to each individual method. The influence of the $\mathrm{Pt} / \mathrm{Ru}$ ratio yielded interesting results for activity as the optimum ratio for $\mathrm{CO}$ oxidation was not found to be the optimum ratio for methanol oxidation. The methanol oxidation onset potential was similar across the $\mathrm{Pt} / \mathrm{Ru}$ ratio range of 40:60-75:25, whilst $\mathrm{CO}$ oxidation onset potential had a clear minimum at 50:50. This shows that the CO oxidation onset potential is more sensitive to changes in $\mathrm{Pt} / \mathrm{Ru}$ ratio than methanol oxidation. Methanol oxidation current at $0.5 \mathrm{~V}$ vs. RHE (A/g $\left.\mathrm{g}_{\text {metal }}\right)$ and chronoamperometry experiments showed a Pt/Ru ratio of 50:50 to be the optimum.

Acknowledgements $\mathrm{CJ}$, OC and PL thank the South African Department of Science and Technology for financial support in the form of HySA/Catalysis Centre of Competence programme funding (OC, PL) and an HySA/Catalysis student bursary (CJ). The authors also acknowledge the Electron Microscopy Unit at the University of Cape Town for assistance with TEM imaging and the Department of Physics from the University of the Free State for XPS measurements.

Open Access This article is distributed under the terms of the Creative Commons Attribution 4.0 International License (http:// creativecommons.org/licenses/by/4.0/), which permits unrestricted use, distribution, and reproduction in any medium, provided you give appropriate credit to the original author(s) and the source, provide a link to the Creative Commons license, and indicate if changes were made.

\section{References}

1. C.H. Hamann, A. Hamnet, W. Vielstich, Electrochemistry, 2nd edn. (Wiley-VCH, Weinheim, 2007)

2. H. Zhang, X. Wang, J.L. Zhang, J.W. Zhang, Electrocatalysts and Catalyst Layers Fundamentals and Applications (Springer, London, 2008)

3. R.K. Shah, Recent Trends in Fuel Cell Science and Technology (Springer, New York, 2007), pp. 1-9

4. A.S. Aricò, S. Srinivasan, V. Antonucci, DMFCs: from fundamental aspects to technology development. Fuel Cells 1(2), 133-161 (2001) 
5. Z.B. Wang, G.P. Yin, P.F. Shi, Stable Pt-Ru/C catalysts prepared from new precursors by thermal reduction for direct methanol fuel cell. J. Electrochem. Soc. 152(12), A2406-A2412 (2005)

6. X. Zhao, G. Sun, L. Jiang, W. Chen, S. Tang, B. Zhou, Q. Xin, Effects of chloride anion as a potential fuel impurity on DMFC performance. Electrochem. Solid-State Lett. 8(3), A149-A151 (2005)

7. C. Thurier, P. Doppelt, Platinum OMCVD processes and precursor chemistry. Coord. Chem. Rev. 252(1-2), 155-169 (2008)

8. J. Zhao, H.O. Marcy, L.M. Tonge, B.W. Wessels, T.J. Marks, C.R. Kannewurf, Science and Technology of Thin Film Superconductors (Springer, US, 1989), pp. 295-299

9. J.R.V. Garcia, T. Goto, Chemical vapor deposition of iridium, platinum, rhodium and palladium. Mater. Trans. 44(9), 1717-1728 (2003)

10. Q. Naidoo, S. Naidoo, L. Petrik, A. Nechaev, P. Ndungu, The influence of carbon based supports and the role of synthesis procedures on the formation of platinum and platinum-ruthenium clusters and nanoparticles for the development of highly active fuel cell catalysts. Int. J. Hydrog. Energy 37(12), 9459-9469 (2012)

11. S. Taylor, E. Fabbri, P. Levecque, T.J. Schmidt, O. Conrad, The effect of platinum loading and surface morphology on oxygen reduction activity. Electrocatalysis 7(4), 287-296 (2016)

12. N.B. Morozova, G.I. Zharkova, P.P. Semyannikov, S.V. Sysoev, I.K. Igumenov, N.E. Fedotova, N.V. Gelfond, Vapor pressure of precursors for CVD on the base of platinum group metals. J. Phys. Chem. IV, France 11, 609-616 (2001)

13. S. Yoda, A. Hasegawa, H. Suda, Y. Uchimaru, K. Haraya, T. Tsuji, K. Otake, Preparation of a platinum and palladium/polyimide nanocomposite film as a precursor of metal-doped carbon molecular sieve membrane via supercritical impregnation. Chem. Mater. 16(12), 2363-2368 (2004)

14. I.K. Igumenov, P.P. Semyannikov, S.V. Trubin, N.B. Morozova, Gelfond, A.V. Mischenko, J.A. Norman, Approach to control deposition of ultra thin films from metal organic precursors: $\mathrm{Ru}$ deposition. Surf. Coat. Technol. 201(22-23), 9003-9008 (2007)

15. C. He, H.R. Kunz, J.M. Fenton, Evaluation of platinum-based catalysts for methanol electro-oxidation in phosphoric acid electrolyte. J. Electrochem. Soc. 144(3), 970-979 (1997)

16. V. Radmilovic, H.A. Gasteiger, P.N. Ross, Structure and chemical composition of a supported Pt-Ru electrocatalyst for methanol oxidation. J. Catal. 154(1), 98-106 (1995)

17. M. Watanabe, M. Uchida, S. Motoo, Preparation of highly dispersed $\mathrm{Pt}+\mathrm{Ru}$ alloy clusters and the activity for the electrooxidation of methanol. J. Electroanal. Chem. Interfacial Electrochem. 229(1-2), 395-406 (1987)

18. E. Antolini, F. Cardellini, Formation of carbon supported PtRu alloys: an XRD analysis. J. Alloys Compd. 315(1-2), 118-122 (2001)

19. Y. Sato, K. Yomogida, T. Nanaumi, K. Kobayakawa, Y. Ohsawa, M. Kawai, Electrochemical behavior of activated-carbon capacitor materials loaded with ruthenium oxide. Electrochem. Solid-State Lett. 3(3), 113-116 (2000)

20. T.R. Ralph, M.P. Hogarth, Catalysis for low temperature fuel cells. Platin. Met. Rev. 46(3), 117-135 (2002)

21. Y.D. Kim, H. Over, G. Krabbes, G. Ertl, Identification of $\mathrm{RuO}_{2}$ as the active phase in $\mathrm{CO}$ oxidation on oxygen-rich ruthenium surfaces. Top. Catal. 14(1-4), 95-100 (2000)

22. C. Bock, M. Blakely, B. MacDougall, Characteristics of adsorbed $\mathrm{CO}$ and $\mathrm{CH}_{3} \mathrm{OH}$ oxidation reactions for complex $\mathrm{Pt} / \mathrm{Ru}$ catalyst systems. Electrochim. Acta 50(12), 2401-2414 (2005)

23. J.W. Long, R.M. Stroud, K. Swider-Lyons, D.R. Rolison, How to make electrocatalysts more active for direct methanol oxidationavoid PtRu bimetallic alloys! J. Phys. Chem. B 104(42), 9772$9776(2000)$

24. L. Giorgi, A. Pozio, C. Bracchini, R. Giorgi, S. Turtù, $\mathrm{H}_{2}$ and $\mathrm{H}_{2}$ $\mathrm{CO}$ oxidation mechanism on $\mathrm{Pt} / \mathrm{C}, \mathrm{Ru} / \mathrm{C}$ and $\mathrm{Pt}-\mathrm{Ru} / \mathrm{C}$ electrocatalysts. J. Appl. Electrochem. 31(3), 325-334 (2001)

25. D.R. Rolison, P.L. Hagans, K.E. Swider, J.W. Long, Role of hydrous ruthenium oxide in Pt-Ru direct methanol fuel cell anode electrocatalysts: the importance of mixed electron/proton conductivity. Langmuir 15(3), 774-779 (1999)

26. H. Hoster, T. Iwasita, H. Baumgärtner, W. Vielstich, Current-time behavior of smooth and porous PtRu surfaces for methanol oxidation. J. Electrochem. Soc. 148(5), A496-A501 (2001)

27. L. Gancs, N. Hakim, B. Hult, S. Mukerjee, Dissolution of Ru from $\mathrm{PtRu}$ electrocatalysts and its consequences in DMFCs. ECS Trans. 3(1), 607-618 (2006)

28. A.K. Datye, Q. Xu, K.C. Kharas, J.M. McCarty, Particle size distributions in heterogeneous catalysts: what do they tell us about the sintering mechanism? Catal. Today 111(1-2), 59-67 (2006)

29. W.F. Lin, M.S. Zei, M. Eiswirth, G. Ertl, T. Iwasita, W. Vielstich, Electrocatalytic activity of Ru-modified Pt(111) electrodes toward CO oxidation. J. Phys. Chem. B 103(33), 6968-6977 (1999)

30. K. Kinoshita, Particle size effects for oxygen reduction on highly dispersed platinum in acid electrolytes. J. Electrochem. Soc. 137(3), 845-848 (1990)

31. S.D. Lin, T. Hsiao, J. Chang, A.S. Lin, Morphology of carbon supported Pt-Ru electrocatalyst and the CO tolerance of anodes for PEM fuel cells. J. Phys. Chem. B 103(1), 97-103 (1999)

32. H.A. Gasteiger, N. Markovic, P.N. Ross, E.J. Cairns, Carbon monoxide electrooxidation on well-characterized platinum-ruthenium alloys. J. Phys. Chem. 98(2), 617-625 (1994)

33. W.H. Lizcano-Valbuena, V.A. Paganin, E.R. Gonzalez, Methanol electro-oxidation on gas diffusion electrodes prepared with $\mathrm{Pt}-\mathrm{Ru} / \mathrm{C}$ catalysts. Electrochim. Acta 47(22-23), 3715-3722 (2002)

34. K. Lasch, L. Jörissen, K.A. Friedrich, J. Garche, The function of ruthenium oxides in Pt-Ru catalysts for methanol electro-oxidation at low temperatures. J. Solid State Electrochem. 7(9), 619-625 (2003)

35. H. Liu, J. Zhang, Electrocatalysis of Direct Methanol Fuel Cells: from Fundamentals to Applications (Wiley, NJ, 2009) 